\title{
Serum dickkopf-1 as a clinical and prognostic factor in non- small cell lung cancer patients with bone metastases
}

\author{
Rong Qiao ${ }^{1, *}$, Runbo Zhong ${ }^{1, *}$, Qing Chang ${ }^{2}$, Jiajun Teng ${ }^{1}$, Jun Pei ${ }^{1}$, Baohui Han ${ }^{1}$ and \\ Tianqing $\mathrm{Chu}^{1}$ \\ ${ }^{1}$ Department of Pulmonary Medicine, Shanghai Chest Hospital, Shanghai Jiao Tong University, Shanghai 200030, People's \\ Republic of China \\ ${ }^{2}$ Shanghai Jiao Tong University School of Medicine, Shanghai 200025, People's Republic of China \\ *These authors contributed equally to this work \\ Correspondence to: Tianqing Chu, email: ctqxkyy@163.com \\ Baohui Han, email: xkyyhan@gmail.com \\ Keywords: dickkopf-1, non-small cell lung cancer, bone metastasis, prognosis, stage IV \\ Received: December 20, $2016 \quad$ Accepted: May 23, $2017 \quad$ Published: June 12, 2017
}

Copyright: Qiao et al. This is an open-access article distributed under the terms of the Creative Commons Attribution License 3.0 (CC BY 3.0), which permits unrestricted use, distribution, and reproduction in any medium, provided the original author and source are credited.

\section{ABSTRACT}

Background: The study was designed to evaluate the association between serum dickkopf-1 (DKK1) and non-small cell lung cancer (NSCLC) bone metastases.

Materials and Methods: Serum DKK1 levels were quantified in 470 NSCLC patients, 140 with osseous metastases, 178 with extraosseous metastases, and 152 with early stage in complete remission. The Receiver Operating Characteristic (ROC) curve enabled us to identify a threshold value to distinguish patients with bone metastases.

Results: Serum DKK1 levels in patients with osseous metastases were significantly higher than in the other 2 groups $(P<0.001)$. ROC curves showed that the optimum cutoff was $311.8 \mathrm{pg} / \mathrm{ml}$ (area under curve $0.791,95 \%$ confidence interval $0.739-0.843$, sensitivity $77.1 \%$ and specificity $71.4 \%$ ). Of interest, serum DKK1 correlated with the number of bone lesions $(P=0.042)$ and associated with the poor survival in NSCLC patients with osseous metastases $(P=0.029)$.

Conclusions: Our data shows that serum DKK1 can be used for the detection of NSCLC bone metastases. More importantly this is the first report to show that serum DKK1 is a good predictor of poor prognosis in NSCLC patients with bone metastases.

\section{INTRODUCTION}

Lung cancer is the leading cause of cancer-related mortality worldwide [1]. Late diagnosis is common, and the majority of patients present with metastatic disease. Bone is one of the predominant metastatic sites of lung cancer, accounting for $30 \%-40 \%$ of patients [2]. The presence of bone metastases is a poor prognostic factor that may induce clinical symptoms, such as pain, pathological fractures, paralysis and hypercalcemia, all of which adversely affect quality of life and treatment outcomes. Monitoring bone metastases is essential for lung cancer management.
Serum carcinoembryonic antigen (CEA) is considered a poor prognostic factor in early-stage nonsmall cell lung cancer (NSCLC) [3-13], but its role in advanced disease is controversial. In a study from Cedrés et al. (2011)[14] which included 277 advanced patients, high CEA levels at diagnosis were an unfavorable prognostic factor; however, these results were not replicated in studies from Kulpa et al. (2002) [15] and Ardizzoni et al. (2006) [16]. Therefore, novel and reliable prognostic biomarkers to complement CEA are urgently needed for clinical use in advanced NSCLC.

The Wnt/ $\beta$-catenin pathway plays a crucial role in tumor pathogenesis, specifically in cell proliferation, 
Table 1: Clinical features of all patients

\begin{tabular}{|c|c|c|c|}
\hline Characteristics & patients with early stage $(N=152)$ & $\begin{array}{l}\text { Patients with osseous } \\
\text { metastases }(N=140)\end{array}$ & $\begin{array}{c}\text { Patients with extraosseous } \\
\text { metastases }(N=178)\end{array}$ \\
\hline Mean age (years) & 59.51 & 57.1 & 59.1 \\
\hline \multicolumn{4}{|l|}{ Gender } \\
\hline male & 98 & 87 & 111 \\
\hline female & 54 & 53 & 67 \\
\hline \multicolumn{4}{|l|}{ ECOG PS } \\
\hline $0-1$ & 150 & 134 & 174 \\
\hline 2 & 2 & 6 & 4 \\
\hline \multicolumn{4}{|l|}{ Smoking history } \\
\hline yes & 89 & 54 & 93 \\
\hline no & 63 & 86 & 85 \\
\hline \multicolumn{4}{|l|}{ Histology } \\
\hline adenocarcinoma & 96 & 100 & 120 \\
\hline squamous carcinoma & 32 & 15 & 22 \\
\hline other NSCLC & 24 & 25 & 36 \\
\hline
\end{tabular}

Abbreviations: NSCLC, non-small cell lung cancer; ECOG PS, Eastern Cooperative Oncology Group performance status; $N$, number.

angiogenesis, motility and invasiveness [17-19], and may also play an important role in the differentiation of osteoblasts [20, 21]. The activity of Wnt family ligands is antagonized by several secreted factors including Dickkopf (DKK). DKK1 blocks Wnt/ $\beta$-catenin signaling by binding low-density lipoprotein receptor-related protein 5 and 6 and preventing receptor-ligand interactions $[22,23]$. It has been reported that DKK1 produced by myeloma cells inhibits osteoblast differentiation in vitro, and increased DKK1 levels in bone marrow plasma and peripheral blood correlate with the presence of lytic bone lesions in myeloma patients [20]. It has also been suggested that breast cancer cells with over-activated Wnt/ $\beta$-catenin signaling produce high levels of DKK1, which is involved in breast cancer-derived osteolytic metastases [24]. As our previous studies described, we have found that lung tumor cell derived DKK1 increases the level of $\beta$-catenin and negatively regulates osteoblast differentiation [25], indicating that lung cancer produced DKK1 may be an important mechanistic link between NSCLC and bone metastases.

However, whether serum DKK1 contributes to bone metastasis and can be used to predict the prognosis of advanced NSCLC patients has not been addressed. In this study, we investigated whether circulating DKK1 levels were associated with bone metastases in NSCLC and explored additional information relating to the severity and prognosis of NSCLC.

\section{RESULTS}

\section{Serum DKK1 levels are increased in NSCLC patents with bone metastases}

This study enrolled 470 NSCLC patients, including 140 with osseous metastases, 178 with extraosseous metastases, and 152 with early stage in complete remission, and DKK1 protein was detected in all serum samples. The baseline characteristics of all patients are shown in Table 1. The mean level of serum DKK1 was $371.44 \mathrm{pg} / \mathrm{ml}$ in patients with osseous metastases. In contrast, the mean levels of serum DKK1 were $260.71 \mathrm{pg} / \mathrm{ml}$ and $160.07 \mathrm{pg} / \mathrm{ml}$ in patients with extraosseous metastases and patients with early stage in complete remission, respectively. The expression of DKK1 in serum was significantly upregulated in patients with osseous metastases compared to patients with early stage in complete remission $(P<0.001)$ and patients with extraosseous metastases $(P<0.001)$. In stage IV, as shown in Table 2, serum DKK1 did not correlate with $N$ stage $(P=0.455), T$ stage $(P=0.761)$, pleura metastases $(P=0.472)$, lung metastases $(P=0.928)$, brain metastases $(P=0.186)$, liver metastases $(P=0.800)$ or adrenal gland metastases $(P=0.838)$. Using the Receiver Operating Characteristic(ROC) curve drawn with these data, a serum level of $311.8 \mathrm{pg} / \mathrm{ml}$ was selected as the optimal cutoff value for detecting NSCLC with bone metastases to get both high sensitivity and high specificity (area under curve [AUC] 0.791, 95\% confidence interval [CI] 0.739-0.843, sensitivity $77.1 \%$ and specificity $71.4 \%$ ). These findings indicated that DKK1 is a potential serum biomarker to distinguish between osseous metastases and extraosseous metastases in stage IV NSCLC patients.

To evaluate the clinical utility of serum DKK1 as a bone metastasis biomarker, we also measured the conventional tumor marker CEA in patients with stage IV. Serum CEA levels were abnormally elevated in 180 out of $287(62.7 \%)$ patients, and significantly higher in the osseous metastases group than the extraosseous metastases group $(P=0.042)$. The optimum cutoff value for CEA was $3.03 \mathrm{ng} / \mathrm{ml}$ (AUC $0.577,95 \%$ CI $0.511-0.644$, sensitivity $81.3 \%$ and specificity $67.1 \%$ ). ROC analysis 
Table 2: Serum DKK1 concentrations in different metastatic organs in all stage IV NSCLC patients $(N=318)$

\begin{tabular}{|c|c|c|c|c|}
\hline Variables & Subgroup & $N$ & DKK1 pg/ml(mean) & $P$ value \\
\hline \multirow[t]{3}{*}{ Bone metastases } & & & & $<0.001$ \\
\hline & yes & 140 & 371.44 & \\
\hline & no & 178 & 260.71 & \\
\hline \multirow[t]{3}{*}{ Pleura metastases } & & & & 0.472 \\
\hline & yes & 135 & 303.74 & \\
\hline & no & 183 & 313.68 & \\
\hline \multirow[t]{3}{*}{ Lung metastases } & & & & 0.928 \\
\hline & yes & 99 & 310.39 & \\
\hline & no & 219 & 309.04 & \\
\hline \multirow[t]{3}{*}{ Brain metastases } & & & & 0.186 \\
\hline & yes & 79 & 324.68 & \\
\hline & no & 239 & 304.43 & \\
\hline \multirow[t]{3}{*}{ Liver metastases } & & & & 0.800 \\
\hline & yes & 29 & 315.66 & \\
\hline & no & 289 & 308.84 & \\
\hline \multirow{3}{*}{ adrenal gland metastases } & & & & 0.838 \\
\hline & yes & 19 & 315.61 & \\
\hline & no & 299 & 309.07 & \\
\hline \multirow[t]{3}{*}{ N stage } & & & & 0.455 \\
\hline & $\mathrm{N} 0+\mathrm{N} 1$ & 49 & 299.39 & \\
\hline & $\mathrm{N} 2+\mathrm{N} 3$ & 269 & 311.29 & \\
\hline \multirow{3}{*}{ T stage } & & & & 0.761 \\
\hline & $\mathrm{T} 1+\mathrm{T} 2$ & 177 & 311.27 & \\
\hline & $\mathrm{T} 3+\mathrm{T} 4$ & 141 & 307.20 & \\
\hline
\end{tabular}

Abbreviations: NSCLC, non-small cell lung cancer; DKK1, Dickkopf-1; N, number.

showed that testing both DKK1 and CEA increased the detection accuracy for NSCLC bone metastases compared with CEA alone (AUC 0.797, 95\% CI 0.746-0.848, sensitivity $82.9 \%$ and specificity $68.9 \%$; DKK1 plus CEA vs. DKK1 alone $P=0.370$; DKK1 plus CEA vs. CEA alone $P=0.0001)$. Thus, serum DKK1 had a greater AUC than CEA in patients with osseous metastases compared with patients with extraosseous metastases (Figure 1, Table 3). As determined by bivariate correlation analysis, the correlation coefficient between serum DKK1 and CEA levels was not significant (correlation coefficient 0.049; $P=0.407$ ), also indicating that measuring both serum markers could improve the overall sensitivity for detecting bone metastases.

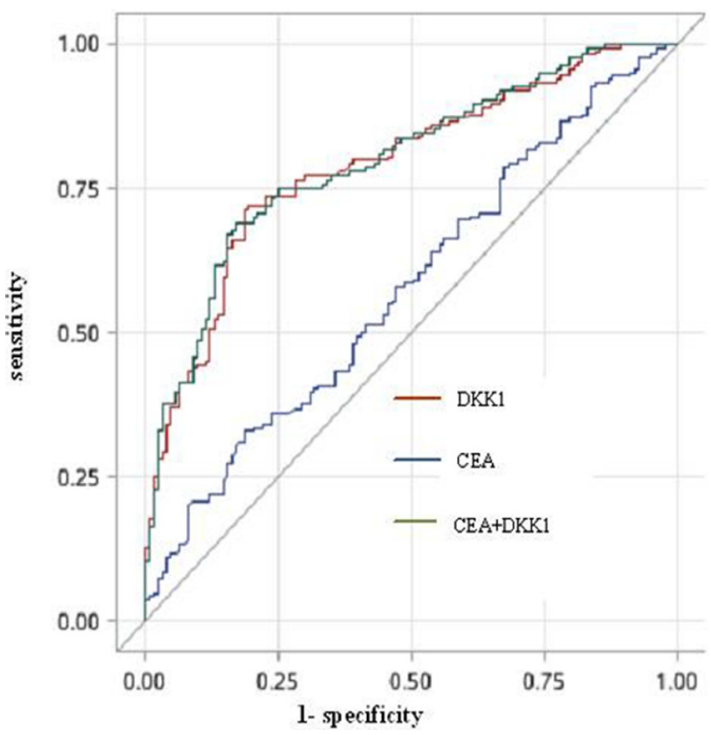

Figure 1: The ROC curve for DKK1, CEA or both for NSCLC patients with osseous metastases versus the extraosseous metastases. Abbreviations: DKK1, Dickkopf-1; CEA, carcinoembryonic antigen; ROC, receiver operating characteristic. 
Table 3: Results for measurement of serum DKK1, CEA or both in detection of bone metastases

\begin{tabular}{lllll}
\hline Variables & AUC (95\% CI) & Cutoff value & Sensitivity (\%) & Specificity (\%) \\
\hline CEA & 0.577 & $3.03(\mathrm{ng} / \mathrm{ml})$ & 81.3 & 67.1 \\
\multirow{2}{*}{ DKK1 } & $0.511-0.644)$ & & & 71.4 \\
\multirow{2}{*}{ CEA + DKK1 } & $\begin{array}{l}0.791 \\
0.739-0.843)\end{array}$ & $311.8(\mathrm{pg} / \mathrm{ml})$ & 77.1 & 68.9 \\
\hline
\end{tabular}

Abbreviations: DKK1, Dickkopf-1; CEA, carcinoembryonic antigen; ROC, receiver operating characteristic; AUC, area under curve.

\section{Association between serum DKK1 levels and clinicopathological parameters in patients with osseous metastases}

In the osseous metastases group, 45 patients had a solitary bone metastasis and 95 had multiple bone metastases; 49 patients had isolated bone metastases and 91 had bone and visceral or cerebral metastases. Serum DKK1 levels were classified as high or low in relation to the cutoff value, which was based on the results of ROC analysis. Patients with osseous metastases $(n=140)$ were divided into groups based on serum DKK1 levels, the high level group (DKK1 $>311.8 \mathrm{pg} / \mathrm{ml}, n=108$ ) and a low level group (DKK1 $\leq 311.8 \mathrm{pg} / \mathrm{ml}, n=32$ ). The relationship between serum DKK1 level and clinicopathological characteristics of these patients were then analyzed as shown in Table 4. High serum DKK1 levels were significantly correlated with age $(P=0.017)$, and intriguingly, also with the number of bone metastases $(P=0.042)$. There was no association with metastatic pattern and the distribution of bone metastases.

\section{High serum DKK1 levels are associated with shorter overall survival in patients with osseous metastases}

The median survival time of patents with bone metastases was 15.2 months. Kaplan-Meier analysis indicated that high DKK1 levels were correlated with poor overall survival $(P=0.025)$ (Figure 2). Predictive value of serum DKK1 in the subgroups of bone metastases, such as in those with solitary bone metastasis, multiple bone metastasis, isolated bone metastases, additional visceral or cerebral metastases, stage $\mathrm{N} 0+\mathrm{N} 1$, stage $\mathrm{N} 2+\mathrm{N} 3$, stage $\mathrm{T} 1+\mathrm{T} 2$ and stage $\mathrm{T} 3+\mathrm{T} 4$ were further investigated. Serum DKK1 also showed prognostic significance in the subgroups of patients with stage N2 + N3, multiple bone metastasis, and additional visceral or cerebral metastases (Figures 3, 4).

Univariate Cox regression analyses revealed significant associations between overall survival and ECOG PS (hazard ratio $[\mathrm{HR}]=3.115 ; P=0.004$ ), $N$ stage $(\mathrm{HR}=1.862 ; P=0.026)$, number of bone metastases $(\mathrm{HR}=2.088 ; P=0.001)$, metastatic pattern $(\mathrm{HR}=1.297$;
$P=0.009)$ and serum DKK1 level $(\mathrm{HR}=1.648$; $P=0.026)$. There were no associations between OS and age, sex or smoking history. Multivariate Cox regression analysis indicated that ECOG PS (HR $=3.956 ; P=0.001)$, serum DKK1 level $(\mathrm{HR}=1.675 ; P=0.029)$, number of bone metastases (HR $=1.904 ; P=0.004)$ and metastatic pattern $(\mathrm{HR}=1.283 ; P=0.022)$ were independent prognostic factors for overall survival in NSCLC patients with bone metastases (Table 5).

\section{DISCUSSION}

DKK1 is a potent inhibitor of $\mathrm{Wnt} / \beta$-catenin signaling $[18,26,27]$ and has also been shown to inhibit osteoblastogenesis in various osteogenic cell lines [20, 28-31]. Elevated serum DKK1 has been found to be associated with worse survival in cancers from multiple organs including the pancreas [32], stomach [33, 34], liver [35, 36], ovary [37], bile duct [38], bladder $[39,40]$, prostate $[41,42]$, breast $[43,44]$, cervix $[45,46]$ and esophagus [47, 48]. Meanwhile, several studies investigated the clinical and prognostic significance of serum DKK1 in NSCLC, and concluded that DKK1 levels increased with the presence of distant metastases, and correlated with poor overall survival [49-51]. Despite these studies, the involvement of DKK1 in lung cancer bone metastases was still unclear. In this study, we found that serum DKK1 levels were significantly higher in patients with bone metastases compared with patients with early stage in complete remission $(P<0.001)$ and patients with extraosseous metastases $(P<0.001)$. Using ROC curves drawn from our results, we obtained a sensitivity of $77.1 \%$ and a specificity of $71.4 \%$ for detecting NSCLC with bone metastases with a DKK1 cutoff level of 311.8 $\mathrm{pg} / \mathrm{ml}$. Combining serum DKK1 and CEA increased the sensitivity to $82.9 \%$, significantly higher than CEA alone $(P=0.0001)$, and there was no correlation between CEA and DKK1. No statistically significant differences between serum DKK1 levels and different extraosseous metastatic sites (pleura, lung, brain, liver and adrenal gland) were found. The reason why serum DKK1 was slightly lower in pleura metastases group in comparison with non-pleura metastases group may be due to the limited number of patient samples. Furthermore, we found that patients 
Table 4: Association between serum DKK1 and clinicopathological characteristics of NSCLC patients with bone metastases $(N=140)$

\begin{tabular}{|c|c|c|c|}
\hline \multirow{2}{*}{ Variables } & \multicolumn{2}{|c|}{ DKK1 } & \multirow{2}{*}{$P$ valuc } \\
\hline & Low & High & \\
\hline Mean age (years) & & & 0.017 \\
\hline$\leq 57.1$ & 21 & 45 & \\
\hline$>57.1$ & 11 & 63 & \\
\hline Gender & & & 0.644 \\
\hline male & 21 & 66 & \\
\hline female & 11 & 42 & \\
\hline ECOG PS & & & 0.351 \\
\hline $0-1$ & 32 & 101 & \\
\hline 2 & 0 & 7 & \\
\hline Smoking history & & & 0.579 \\
\hline yes & 11 & 43 & \\
\hline no & 21 & 65 & \\
\hline Histology & & & 0.077 \\
\hline adenocarcinoma & 27 & 73 & \\
\hline nonadenocarcinoma & 5 & 35 & \\
\hline $\mathrm{N}$ stage & & & 0.330 \\
\hline $\mathrm{N} 0+\mathrm{N} 1$ & 6 & 13 & \\
\hline $\mathrm{N} 2+\mathrm{N} 3$ & 26 & 95 & \\
\hline T stage & & & 0.810 \\
\hline $\mathrm{T} 1+\mathrm{T} 2$ & 20 & 70 & \\
\hline $\mathrm{T} 3+\mathrm{T} 4$ & 12 & 38 & \\
\hline Number of bone metastases & & & 0.042 \\
\hline solitary bone metastases & 15 & 30 & \\
\hline multiple bone metastases & 17 & 78 & \\
\hline Metastatic pattern & & & 0.353 \\
\hline additional visceral or cerebral metastases & 23 & 68 & \\
\hline isolated bone metastases & 9 & 40 & \\
\hline \multicolumn{4}{|l|}{ Distribution of bone metastases } \\
\hline thorax & & & 0.643 \\
\hline yes & 19 & 69 & \\
\hline no & 13 & 39 & \\
\hline vertebrae & & & 0.317 \\
\hline yes & 17 & 68 & \\
\hline no & 15 & 40 & \\
\hline pelvis & & & 0.317 \\
\hline yes & 15 & 40 & \\
\hline no & 17 & 68 & \\
\hline $\operatorname{limb}$ & & & 0.135 \\
\hline yes & 14 & 32 & \\
\hline no & 18 & 76 & \\
\hline skull & & & 0.987 \\
\hline yes & 5 & 17 & \\
\hline no & 27 & 91 & \\
\hline
\end{tabular}

Abbreviations: ECOG PS, Eastern Cooperative Oncology Group performance status; DKK1, Dickkopf-1. 


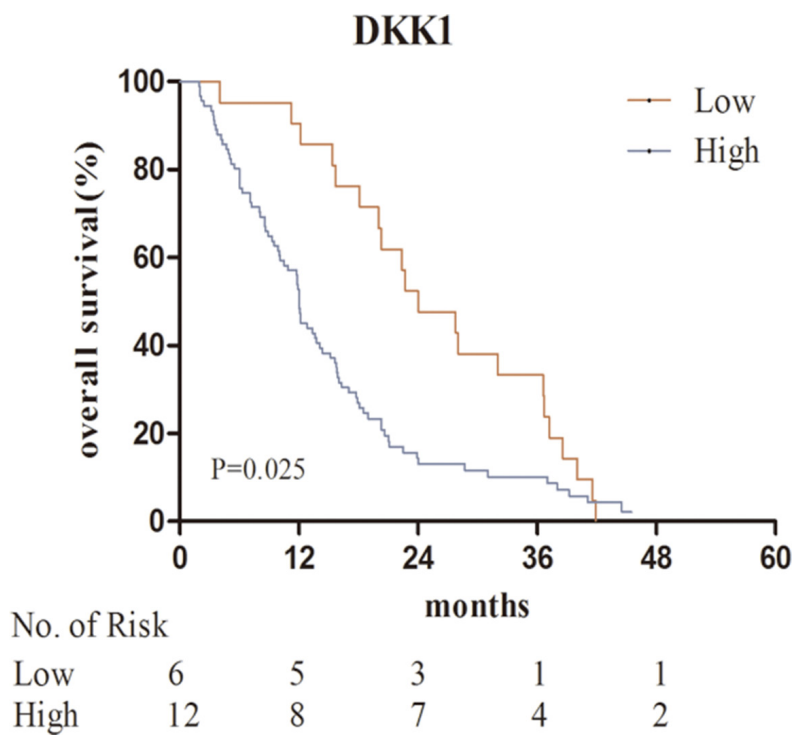

Figure 2: Kaplan-Meier analysis for serum DKK1 in the bone metastases group. Abbreviations: DKK1, Dickkopf-1.

A

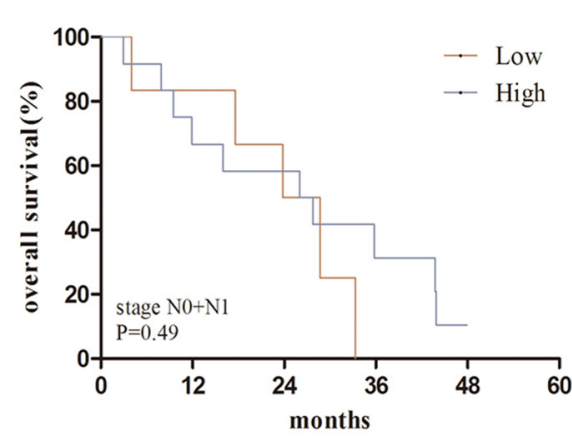

No. of Risk

$\begin{array}{llllll}\text { Low } & 6 & 5 & 3 & 1 & 1 \\ \text { High } & 12 & 8 & 7 & 4 & 2\end{array}$

C

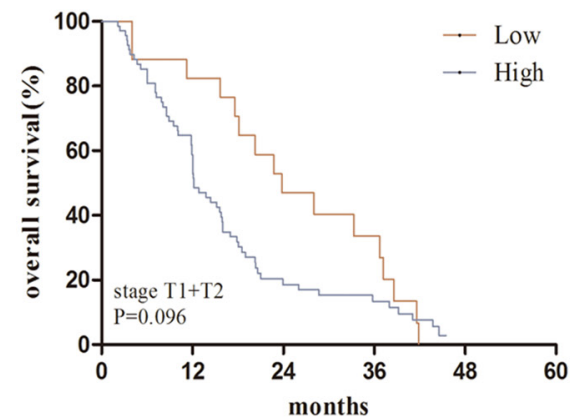

No. of Risk

$\begin{array}{llcccc}\text { Low } & 17 & 14 & 8 & 6 & 1 \\ \text { High } & 68 & 37 & 14 & 11 & 6\end{array}$
B

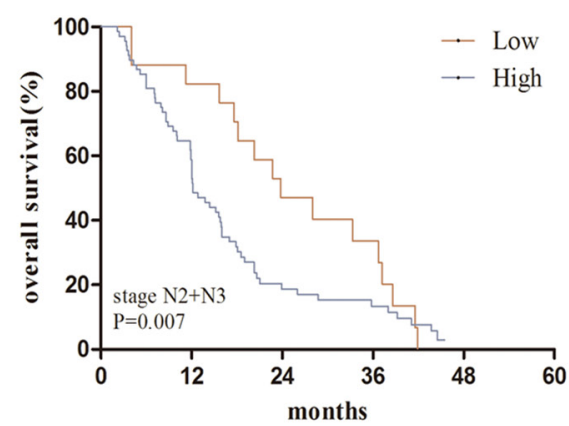

No. of Risk

$\begin{array}{llllcl}\text { Low } & 21 & 19 & 11 & 7 & 0 \\ \text { High } & 91 & 45 & 14 & 12 & 7\end{array}$

D

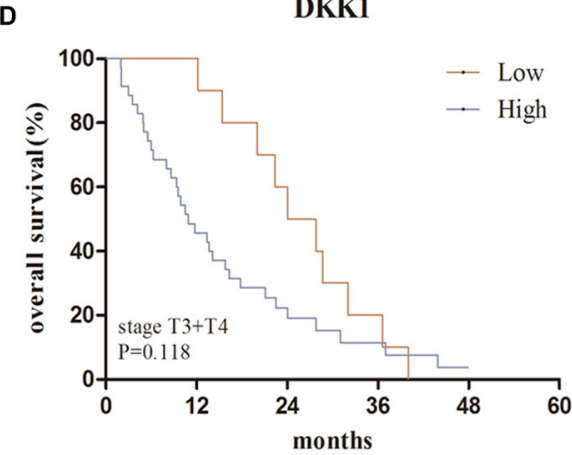

No. of Risk

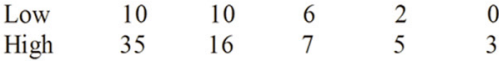

Figure 3: Kaplan-Meier analysis for serum DKK1 in the subgroups of bone metastases. (A, B) patients with stage N0 + N1, $\mathrm{N} 2+\mathrm{N} 3 ;(\mathbf{C}, \mathbf{D})$ patients with stage T1 + T2, T3 + T4. Abbreviations: DKK1, Dickkopf-1. 
with higher serum DKK1 levels were more likely to have multiple bone metastases. However, we also found that serum DKK1 levels did not differ significantly with metastatic pattern and the distribution of bone metastases. Our study suggested that elevated serum DKK1 level could be a marker for the presence of bone metastases in NSCLC, as well as breast cancer [43], multiple myeloma [52] and prostate cancer [53].

With respect to the results of survival analysis in patients with bone metastases, multivariate analysis identified that serum DKK1 levels and number of bone metastases were independent prognostic predictors for OS ( $P=0.029, P=0.004$, respectively). Moreover, KaplanMeier analysis indicated that high serum DKK1 levels were correlated with poor overall survival $(P=0.025)$. Further prognostic analysis in clinical subgroups showed high serum DKK1 levels were associated with bad survival in patients with multiple bone metastasis. All these results confirmed that serum DKK1 could be used to predict the prognosis of NSCLC patients with bone

A

DKK1

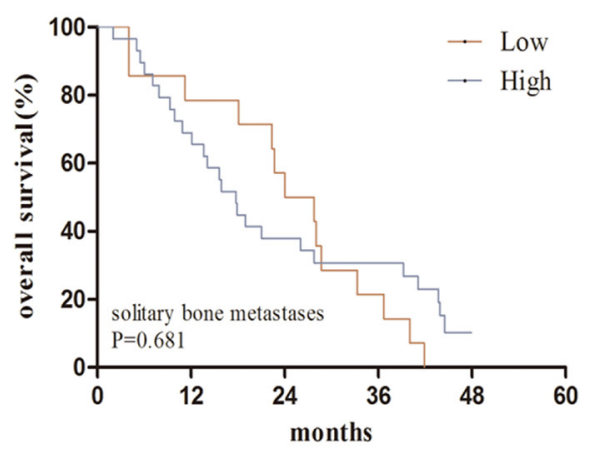

No. of Risk

$\begin{array}{lllcll}\text { Low } & 14 & 11 & 8 & 3 & 0 \\ \text { High } & 29 & 20 & 11 & 9 & 4\end{array}$

C

DKK1

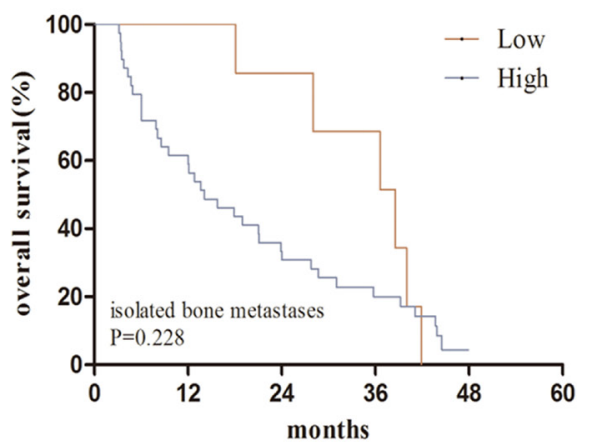

No. of Risk

$\begin{array}{llllll}\text { Low } & 7 & 7 & 6 & 5 & 1 \\ \text { High } & 39 & 23 & 12 & 8 & 3\end{array}$

metastases. To our knowledge, this is the first study to comprehensively investigate the association between serum DKK1 and NSCLC bone metastases. Because the number of serum samples we tested was limited, our results are just preliminary and might have some limits. A larger number of lung cancer samples need to be collected and more studies are also needed to corroborate our results. Further investigation on the function and mechanism of DKK1 in the bone metastasis of NSCLC is awaited.

Our results suggested that DKK1 plays an important role in lung cancer bone metastasis, and serum DKK1 may be a potential tumor biomarker of clinical prognostic value. No reported studies have investigated serum DKK1 in NSCLC patients with bone metastases. However, the mechanism underlying why DKK1 overexpression predicted poor prognosis for NSCLC patients with bone metastases is unclear. Further studies are required to delineate the role of DKK1 in the bone metastases of NSCLC.

B

DKK1

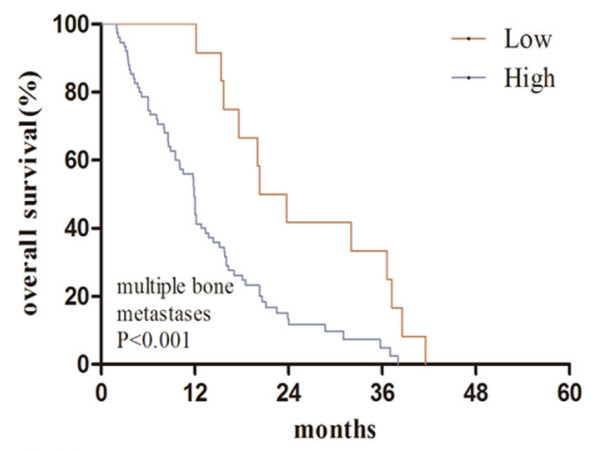

$\begin{array}{lccccc}\text { No. of Risk } & & & & \\ \text { Low } & 13 & 13 & 6 & 5 & 1 \\ \text { High } & 74 & 33 & 10 & 7 & 5\end{array}$

\section{D}

DKK1

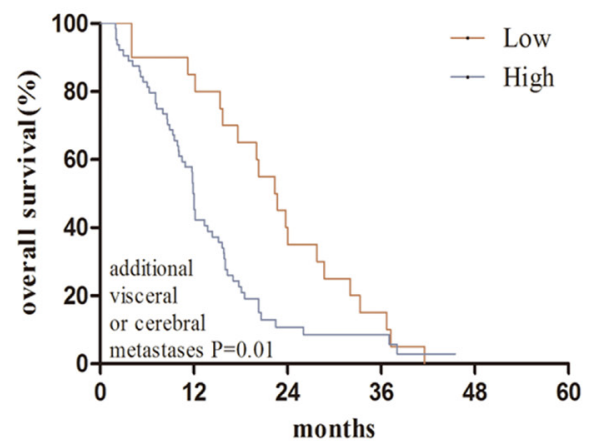

$\begin{array}{llllll}\text { No. of Risk } & & & & \\ \text { Low } & 20 & 17 & 8 & 3 & 0 \\ \text { High } & 64 & 30 & 9 & 8 & 6\end{array}$

Figure 4: Kaplan-Meier analysis for serum DKK1 in the subgroups of bone metastases. (A, B) patients with solitary bone metastasis, multiple bone metastasis; $(\mathbf{C}, \mathbf{D})$ patients with isolated bone metastases, bone and visceral or cerebral metastases. Abbreviations: DKK1, Dickkopf-1. 
Table 5: Univariate and multivariate analyses for prognostic factors in NSCLC patients with bone metastases $(N=140)$

\begin{tabular}{|c|c|c|c|c|}
\hline \multirow{2}{*}{ Variables } & \multirow{2}{*}{$\frac{\text { OS (univariate) }}{\text { Hazard ratio }(95 \% \mathrm{CI})}$} & \multirow{2}{*}{$P$ value } & OS (multivariate) & \multirow{2}{*}{$P$ value } \\
\hline & & & Hazard ratio $(95 \% \mathrm{CI})$ & \\
\hline $\begin{array}{l}\text { Age } \\
(\leq 57.1 \mathrm{vs} .>57.1)\end{array}$ & $\begin{array}{c}1.036 \\
(0.722-1.486)\end{array}$ & 0.850 & $\begin{array}{c}1.124 \\
(0.763-1.655)\end{array}$ & 0.554 \\
\hline $\begin{array}{l}\text { Gender } \\
\text { (male vs. female) }\end{array}$ & $\begin{array}{c}0.970 \\
(0.671-1.402)\end{array}$ & 0.870 & $\begin{array}{c}0.657 \\
(0.401-1.076)\end{array}$ & 0.095 \\
\hline $\begin{array}{l}\text { ECOG PS } \\
(0-1 \text { vs. } 2)\end{array}$ & $\begin{array}{c}3.115 \\
(1.429-6.790)\end{array}$ & 0.004 & $\begin{array}{c}4.053 \\
(1.799-9.127)\end{array}$ & 0.001 \\
\hline $\begin{array}{l}\text { Smoking history } \\
\text { (yes vs. no) }\end{array}$ & $\begin{array}{c}0.937 \\
(0.647-1.357)\end{array}$ & 0.730 & $\begin{array}{c}0.679 \\
(0.411-1.122)\end{array}$ & 0.131 \\
\hline $\begin{array}{l}\text { N phase } \\
(\mathrm{N} 0+\mathrm{N} 1 \text { vs. } \mathrm{N} 2+\mathrm{N} 3)\end{array}$ & $\begin{array}{c}1.862 \\
(1.077-3.217)\end{array}$ & 0.026 & $\begin{array}{c}1.565 \\
(0.874-2.802)\end{array}$ & 0.132 \\
\hline $\begin{array}{l}\text { Number of bone metastases } \\
\text { (solitary vs. multiple) }\end{array}$ & $\begin{array}{c}2.088 \\
(1.379-3.161)\end{array}$ & 0.001 & $\begin{array}{c}1.904 \\
(1.227-2.954)\end{array}$ & 0.004 \\
\hline $\begin{array}{l}\text { Metastatic pattern } \\
\text { (isolated bone vs. bone and other organs) }\end{array}$ & $\begin{array}{c}1.297 \\
(1.066-1.578)\end{array}$ & 0.009 & $\begin{array}{c}1.283 \\
(1.036-1.588)\end{array}$ & 0.022 \\
\hline $\begin{array}{l}\text { Serum DKK1 levels } \\
\text { (low vs. high) }\end{array}$ & $\begin{array}{c}1.648 \\
(1.060-2.561) \\
\end{array}$ & 0.026 & $\begin{array}{c}1.675 \\
(1.055-2.660) \\
\end{array}$ & 0.029 \\
\hline
\end{tabular}

Abbreviations: NSCLC, non-small cell lung cancer; OS, overall survival; ECOG PS, Eastern Cooperative Oncology Group performance status; CI, confidence interval; DKK1, Dickkopf-1.

\section{MATERIALS AND METHODS}

\section{Patients and serum samples}

Serum samples were collected from 140 patients with osseous metastases, 178 patients with extraosseous metastases, and 152 patients with early stage in complete remission admitted to Shanghai Chest Hospital from October 2011 to April 2012. Blood samples were collected before any treatment, and stored at $-80^{\circ} \mathrm{C}$. The study was approved by the ethical committees of Shanghai Chest Hospital and informed consent was signed by each patient. The enrollment criteria for all patients in this study were as follows: 1) pathologically proven primary NSCLC diagnosis; 2) Eastern Cooperative Oncology Group performance status (ECOG PS) 0-2;3) life expectancy not less than 3 months; 4) no history of other cancers.

The following factors were evaluated: age; sex; histology; extent of primary lesion ( $T$ stage); involvement of regional lymph nodes ( $N$ stage); evidence of metastases to brain, liver, bone, lung, pleura, lymph node, pericardium, subcutaneous nodule or adrenal gland (M stage); performance status grade; serum DKK1 and CEA levels. Tumor stage was determined according to the 2009 tumor-node-metastasis (TNM) staging system.

Serum DKK1 levels were measured by enzymelinked immunosorbent assay (ELISA) with an immunoassay kit (Miltenyi, Bergisch Gladbach, Germany) according to the manufacturer's directions and measuring optical density at $450 \mathrm{~nm}$. Results are reported as the concentration of DKK1 (pg/ml) in samples. Serum CEA levels were analyzed using a Quantitative assay kit (Roche Diagnostic GmbH, Basel, Switzerland) with an upper limit of $5 \mathrm{ng} / \mathrm{ml}$ defined as normal according to the kit's manufacturer.

Skeletal metastases were classified into five regions [54]: thorax (rib, clavicle, sternum and scapula), vertebrae (thoracic, lumbar and cervical spine), pelvis (ilium, ischium, pubis, sacrum and sacroiliac regions), limb (upper and lower extremities) or skull. Metastatic load was divided into solitary and multiple bone metastases. Metastatic pattern was divided into isolated bone and bone with visceral or cerebral metastases.

\section{Statistical analysis}

Overall survival (OS) was calculated from the date of diagnosis until the date of mortality or the last follow-up date. Differences in serum DKK1 levels between groups were assessed by $t$ test. Correlations between serum DKK1 levels and clinicopathological characteristics were estimated using $\chi^{2}$ or Fisher's exact test. Receiver operating characteristics (ROC) curves were constructed to assess sensitivity, specificity and respective areas under the curves (AUCs) with 95\% confidence intervals (CIs). We investigated the optimum cutoff value by maximizing the sum of sensitivity and specificity. Survival curves were estimated using the Kaplan-Meier method, and the log-rank test was used to compute differences between the curves. Multivariate analysis using the Cox proportional hazards regression model was performed to assess the prognostic value 
of serum DKK1 levels. All $P$ values were two-tailed, $P<0.05$ was taken to be significant and $95 \%$ CIs for results were calculated, where appropriate. Data were analyzed using SAS 9.4 (SAS Institute, Cary, NC, USA).

\section{ACKNOWLEDGMENTS AND FUNDING}

This work was supported by the Western Medicine Guide Project of Shanghai Committee of Science and Technology (Grant No.16411964700), the Science and Technology Development Fund of Shanghai Chest Hospital (Grant No. 2014YZDC10101), and the Fund of Vascular Targeted therapy in Oncology of CSCO (Grant No.Y-S2015-007).

\section{CONFLICTS OF INTEREST}

The authors declare no conflicts of interest

\section{REFERENCES}

1. Jemal A, Bray F, Center MM, Ferlay J, Ward E, Forman D. Global cancer statistics. CA Cancer J Clin. 2011; 61:69-90.

2. Al Husaini H, Wheatley-Price P, Clemons M, Shepherd FA. Prevention and management of bone metastases in lung cancer. J Thorac Oncol. 2009; 4:251-259.

3. Rubins JB, Dunitz J, Rubins HB, Maddaus MA, Niewoehner DE. Serum CEA as an adjunct to preoperative staging of lung cancer. J Thorac Cardiovasc Surg. 1998; 116:412-416.

4. Matsuoka K, Sumitomo S, Nakashima N, Mikasi N. Prognostic value of CEA and CYFRA21-1 in patients with pathological stage I NSCLC. Eur J Cardiothorac Surg. 2007; 32:435-439.

5. Hotta K, Segwa Y, Takigawa N, Kishino D, Saeki H, Nakata M, Mandai K, Eguchi K. Evaluation of the relationship between serum CEA level and treatment outcome in surgically resected clinical-stage I patients with non-smallcell lung cancer. Anticancer Res. 2000; 20:2177-2180.

6. Icard P, Regnard JF, Essomba A, Panebianco V, Levasseur P, Magdelleinat P. Preoperative carcinoembryonic antigen level as a prognostic indicator in resected primary lung cancer. Ann Thorac Surg. 1994; 58:811-814.

7. Muley T, Dienemann H, Ebert W. CYFRA21-1 and CEA are independent prognostic factors in 153 operated stage I NSCLC patients. Anticancer Res. 2004; 24:1953-1956.

8. Tomita M, Shimizu T, Ayabe T, Yonei A, Onitsuka T. Prognostic significance of tumour marker index based on preoperative CEA and CYFRA21-1 in NSCLC. Anticancer Res. 2010; 30:3099-4102.

9. Suzuki K, Nagai K, Yohida J, Moriyama E, Nishimura M, Takahashi K, Nishiwaki Y. Prognostic factors in clinical stage I NSCLC. Ann Thorac Surg. 1999; 67:927-932.

10. Sawabata N, Ohta M, Takeda S-I, Hirano H, Okumura Y, Asada H, Maeda H. Serum CEA level in surgically resected clinical stage I patients with NSCLC. Ann Thorac Surg. 2002; 74:174-179.

11. Diez M, Torres A, Maestro ML, Ortega MD, Gomez A, Pollan M, Lopez JA, Picardo A, Hernando F, Balibrea JL. Prediction of survival and recurrence by serum and cytosolic levels of CEA.CA-125 and SCC antigens in resectable non-small-cell lung cancer. Br J Cancer. 1996; 73:1248-1254.

12. Kashiwabara, Saeki S, Sasaki J, Nomura M, Kohrogi H. Combined elevation of postoperative serum levels of CEA less than or equal to $2.5 \mathrm{ng} / \mathrm{ml}$ and absence of vascular invasion may predict no recurrence of stage I adenocarcinoma lung cancer. J Thorac Oncol. 2008; 3:1416-1420.

13. Buccheri G, Ferringo D. Identifying patients at risk of early postoperative recurrence of lung cancer: a new use of the old CEA test. Ann Thorac Surg. 2003; 75:973-980.

14. Cedrés S, Nuñez I, Longo M, Martinez P, Checa E, Torrejón D, Felip E. Serum tumor markers CEA, CYFRA21-1, and CA-125 are associated with worse prognosis in advanced non-small-cell lung cancer (NSCLC). Clin Lung Cancer. 2011; 12:172-179.

15. Kulpa J, Wójcik E, Reinfuss M, Kołodziejski L. Carcinoembryonic antigen, squamous cell carcinoma antigen, CYFRA 21-1, and neuron-specific enolase in squamous cell lung cancer patients. Clin Chem. 2002; 48: 1931-1937.

16. Ardizzoni A, Cafferata MA, Tiseo M, Filiberti R, Marroni P, Grossi F, Paganuzzi M. Decline serum carcinomebryonic antigen and cytokeratin 19 fragment during chemotherapy predicts objective response and survival in patients with advanced non small cell lung cancer. Cancer. 2006; 107:2842-2849.

17. Ogoshi K, Kasamatsu AM, Iyoda Ogoshi K, Kasamatsu A, Iyoda M, Sakuma K, Yamatoji M, Sakamoto Y, Ogawara K, Shiiba M, Tanzawa H, Uzawa K. Dickkopf-1 in human oral cancer. Int J Oncol. 2011; 39:329-336.

18. Glinka A, Wu W, Delius H, Monaghan AP, Blumenstock C, Niehrs C. Dickkopf-1 is a member of a new family of secreted proteins and functions in head induction. Nature. 1998; 391:357-362.

19. Niida A, Hiroko T, Kasai M, Furukawa Y, Nakamura Y, Suzuki Y, Sugano S, Akiyama T. Dkk1, a negative regulator of wnt signaling, is a target of the beta-catenin/tcf pathway. Oncogene. 2004; 23:8520-8526.

20. Tian E, Zhan F, Walker R, Rasmussen E, Ma Y, Barlogie B, Shaughnessy J. The role of the wnt-signaling antagonist Dkk1 in the development of osteolytic lesions in multiple myeloma. N Engl J Med. 2003; 349:2483-2494.

21. Hall CL, Bafico A, Dai J, Aaronson SA, Keller ET. Prostate cancer cells promote osteoblastic bone metastases through Wnts. Cancer Res. 2005; 65:7554-7560.

22. Semënov MV, Tamai K, Brott BK, Kühl M, Sokol S, He X. Head inducer Dickkopf-1 is a ligand for Wnt coreceptor LRP6. Curr Biol. 2001; 11:951-961. 
23. Brott B, Sokol S. Regulation of Wnt/LRP signaling by distinct domains of dickkopf proteins. Mol Cell Biol. 2002; 22:6100-6110.

24. Bu G, Lu W, Liu CC, Selander K, Yoneda T, Hall C, Keller ET, Li Y. Breast cancer-derived Dickkopf1 inhibits osteoblast differentiation and osteoprotegerin expression: implication for breast cancer osteolytic bone metastases. Int J Cancer. 2008; 123:1034-1042.

25. Chu T, Teng J, Jiang L, Zhong H, Han B. Lung cancerderived Dickkopfl is associated with bone metastasis and the mechanism involves the inhibition of osteoblast differentiation. Biochem Biophys Res Commun. 2014; 443:962-968.

26. Fedi P, Bafico A, Nieto Soria A, Burgess WH, Miki T, Bottaro DP, Kraus MH, Aaronson SA. Isolation and biochemical characterization of the human DKK-1 homologue, a novel inhibitor of mammalian Wnt signaling. J Biol Chem. 1999; 274:19465-19472.

27. Grotewold L, Theil T, Rüther U. Expression pattern of Dkk-1 during mouse limb development. Mech Dev. 1999; 89:151-153.

28. Rawadi G, Vayssie're B, Dunn F, Baron R, RomanRoman S. BMP-2 controls alkaline phosphatase and osteoblast mineralization by a Wnt autocrine loop. J Bone Miner Res. 2003; 18:1842- 1853.

29. Gunn W, Conley A, Deininger L, Olson S, Prockop D, Gregory C. A crosstalk between myeloma cells and marrow stromal cells stimulates production of DKK1 and interleukin-6: A potential role in the development of lytic bone disease and tumor progression in multiple myeloma. Stem Cells. 2006; 24:986-991.

30. Fujita K, Janz S. Attenuation of WNT signaling by DKK1 and -2 regulates BMP2-induced osteoblast differentiation and expression of OPG, RANKL and M-CSF. Mol Cancer. 2007; 6:71.

31. Giuliani N, Colla S,Morandi F, LazzarwttiM, Sala R, Bonomini S, Grano M, Colucci S, Svaldi M, Rizzoli V. Myeloma cells block RUNX2/CBFA1 activity in human bone marrow osteoblast progenitors and inhibits osteoblast formation and differentiation. Blood. 2005; 106:2472-2483.

32. Han SX, Zhou X, Sui X, He CC, Cai MJ, Ma JL, Zhang YY, Zhou CY, Ma CX, Varela-Ramirez A, Zhu Q. Serum Dickkopf-1 is a novel serological biomarker for the diagnosis and prognosis of pancreatic cancer. Oncotarget. 2015; 6:19907-19917. doi: 10.18632/oncotarget.4529.

33. Gao C, Xie R, Ren C, Yang X. Dickkopf-1 expression is a novel prognostic marker for gastric cancer. J Biomed Biotechnol. 2012; 2012:804592.

34. Lee HS, Lee HE, Park Do J, Kim HH, Kim WH, Park KU. Clinical significance of serum and tissue dickkopf-1 levels in patients with gastric cancer. Clin Chim Acta. 2012; 413:1753-1760.

35. Yang H, Chen GD, Fang F, Liu Z, Lau SH, Zhang JF, Lau WY, Yang LY. Dickkopf-1: as a diagnostic and prognostic serum marker for early hepatocellular carcinoma. Int J Biol Markers. 2013; 28:286-297.

36. Yu B, Yang X, Xu Y, Yao G, Shu H, Lin B, Hood L, Wang H, Yang S, Gu J, Fan J, Qin W. Elevated expression of dkk1 is associated with cytoplasmic/nuclear betacatenin accumulation and poor prognosis in hepatocellular carcinomas. J Hepatol. 2009; 50:948-957.

37. ShizhuoW, Tao J, Shulan Z, Bing Z. The expression and significance of dickkopf-1 in epithelial ovarian carcinoma. Int J Biol Markers. 2009; 24:165-170.

38. Shi RY, Yang XR, Shen QJ, Yang LX, Xu Y, Qiu SJ, Sun YF, Zhang X, Wang Z, Zhu K, Qin WX, Tang ZY, Fan J, et al. High expression of Dickkopf-related protein 1 is related to lymphatic metastasis and indicates poor prognosis in intrahepatic cholangiocarcinoma patients after surgery. Cancer. 2013; 119:993-1003.

39. Kaba M, Pirincci N, Benli E, Gecit I, Gunes M, Yuksel MB, Tok A, Kemik AS. Dickkopf-1 levels in Turkish patients with bladder cancer and its association with clinicopathological features. Asian Pac J Cancer Prev. 2014; 15:381-384.

40. Sun DK, Wang L, Wang JM, Zhang P. Serum Dickkopf-1 levels as a clinical and prognostic factor in patients with bladder cancer. Genet Mol Res. 2015; 14:18181-18187.

41. Hall CL, Daignault SD, Shah RB, Pienta KJ, Keller ET. Dickkopf-1 expression increases early in prostate cancer development and decreases during progression from primary tumor to metastasis. Prostate. 2008; 68:1396-1404.

42. Rachner TD, Thiele S, Göbel A, Browne A, Fuessel S, Erdmann K, Wirth MP, Fröhner M, Todenhöfer T, Muders MH, Kieslinger M, Rauner M, Hofbauer LC. High serum levels of Dickkopf-1 are associated with a poor prognosis in prostate cancer patients. BMC Cancer. 2014; 14:649.

43. Voorzanger-Rousselot N, Goehrig D, Journe F, Doriath V, Body JJ, Clezardin P ,Garnero P. Increased Dickkopf-1 expression in breast cancer bone metastases. Br J Cancer. 2007; 97:964-970.

44. Zhou SJ, Zhuo SR, Yang XQ, Qin CX, Wang ZL. Serum Dickkopf-1 expression level positively correlates with a poor prognosis in breast cancer. Diagn Pathol. 2014; 9:161.

45. Jiang T, Huang L, Zhang S. Dkk-1 in serum as a clinical and prognostic factor in patients with cervical cancer. Int J Biol Markers. 2013; 28:221-225.

46. Jiang T, Wang S, Huang L, Zhang S. Clinical significance of serum DKK-1 in patients with gynecological cancer. Int J Gynecol Cancer. 2009; 19:1177-1181.

47. Makino T, Yamasaki M, Takemasa I, Takeno A, Nakamura Y, Miyata H, Takiguchi S, Fujiwara Y, Matsuura N, Mori M, Doki Y. Dickkopf-1 expression as a marker for predicting clinical outcome in esophageal squamous cell carcinoma. Ann Surg Oncol. 2009; 16:2058-2064.

48. Yamabuki T, Takano A, Hayama S, Ishikawa N, Kato T, Miyamoto $\mathrm{M}$, Ito $\mathrm{T}$, Ito $\mathrm{H}$, Miyagi $\mathrm{Y}$, Nakayama $\mathrm{H}$. Dikkopf-1 as a novel serologic and prognostic biomarker 
for lung and esophageal carcinomas. Cancer Res. 2007; 67:2517-2525.

49. Xu H, Wu J, Chen B, Li M, Tian Y, He M, Xue J, Wang J, Bai S, Sharma A, Liu H, Tang J, She JX. Serum Dickkopf-1 (DKK1) is significantly lower in patients with lung cancer but is rapidly normalized after treatment. Am J Transl Res. 2014; 6:850-856.

50. Dong LL, Qu LY, Chu LY, Zhang XY, Liu YY. Serum level of DKK-1 and its prognostic potential in non-small cell lung cancer. Diagn Pathol. 2014; 9:52.

51. Le Sheng S, Huang G, Yu B, Qin WX. Clinical significance and prognostic value of serum Dickkopf-1 concentrations in patients with lung cancer. Clin Chem. 2009; 55:1656-1664.

52. Kaiser $M$, Mieth $M$, Liebisch $P$, Oberländer $R$, Rademacher J, Jakob C, Kleeberg L, Fleissner C,
Braendle E, Peters M, Stover D, Sezer O, Heider U. Serum concentrations of DKK-1 correlate with the extent of bone disease in patients with multiple myeloma. Eur J Haematol. 2008; 80:490-494.

53. Hall CL, Daignault SD, Shah RB, Pienta KJ, Keller ET. Dickkopf-1 expression increases early in prostate cancer development and decreases during progression from primary tumor to metastasis. Prostate. 2008; 68:1396-1404.

54. Wilson MA, Calhoun FW. The distribution of skeletal metastases in breast and pulmonary cancer: concise communication. J Nucl Med. 1981; 22:594-597. 